\title{
The Novelty and the Compound Marine Engine in Central Canada ${ }^{1}$
}

\section{Walter Lewis}

La machine à vapeur marine composée, bien que développée dès les années 1820, n'a pas vu une utilisation répandue sur les Grands Lacs jusqu'à la fin des années 1860. Cet article aide à expliquer pourquoi, en analysant les ressources archivistiques sur la carrière du vapeur Novelty, qui a servi pendant la plupart de sa carrière entre Kingston et la Baie de Quinté dans les années 1850. Il était le premier vapeur équipé d'un moteur composé pour opérer sur les côtes canadiennes des grands lacs, et a souffert une série d'échecs mécaniques et d'autres mésaventures avant sa perte dans une collision avec un autre navire. Ses machines innovatrices semblent avoir été bien au-delà de la capacité technique de son équipage et de la Fonderie de Kingston, la société contractée pour maintenir ses machines en état de fonctionnement.

Apart from the introduction of the propeller in the 1840 s there is perhaps no element in the development of marine steam engines more significant than that of compounding. In the first half of the nineteenth century virtually all marine engines were single cylinder. Steam was generated in the boiler and passed to the cylinder. In "high pressure" engines it was used expansively to drive the piston; in "low pressure" engines it was condensed to create a vacuum and draw the piston. Compound engines, in simple terms, worked the steam work harder by combining these two actions: first driving the high pressure cylinder and then releasing the steam, either directly or through an intermediate chamber, into the low pressure cylinder. Theoretically, by getting more work out of the steam, less steam would have to be generated with significant savings in fuel. Like many relatively simple concepts, the compound, or double-expansion, engine was "invented" a number of times by different people in different places engaged in the common pursuit of greater efficiency in the production of motive power. The engine of

1 This paper was inspired by a "thread" in February 1997 on the origins of the compound engine, and specifically on Tibbets' role, on MarHst-1, the internet discussion group on maritime history and maritime museums. The thread revived in the spring of 2009. The author would like to acknowledge the assistance of Rollie Webb (for starting the discussion), Rick Neilson, Stephen Salmon, Eileen Marcil, Gilbert Bossé, David McGee, Maurice Smith, A. Steven Toby and Keith Allen.

The Northern Mariner/le marin du nord, XIX No. 4, (October 2009), 413-424 


\section{Schematic: the principle of the compound engine}

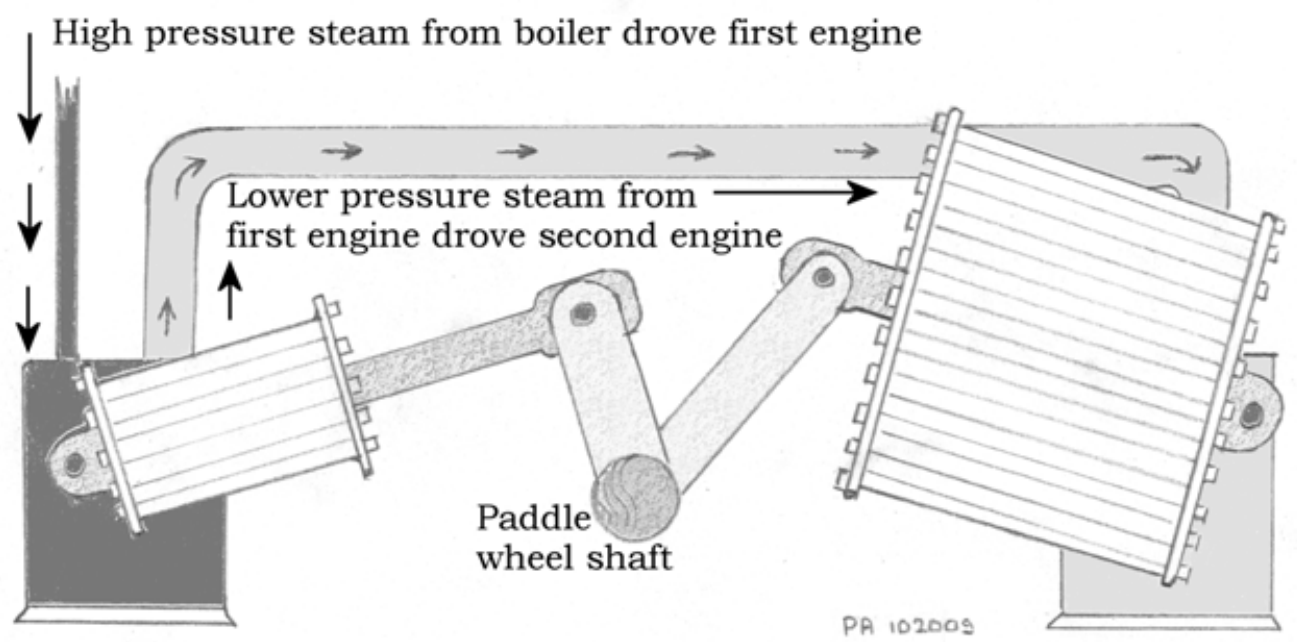

90. Compound Engines, called also High and Low Pressure Engines.-A compound engine is an engine with two cylinders, the one frequently double the diameter of the other. Steam is admitted from the boiler into the smaller cylinder, and after it has driven the piston up or down it is then allowed to pass into the larger cylinder, when, by its expansive property, it drives the larger piston down or up.

The theory of the action of compound engines is simply this : that a great initial velocity given to a piston does more economical work than a pressure continued throughout the stroke, as has been fully explained in expansive working; and if this initial velocity be given on a small surface it does most work, while, if the steam have less power, it will do most work acting upon a larger surface. For convenience, economy in working, and economy in construction, the principles of making the initial steam act upon a small surface of piston is the correct one, the larger surface being acted upon by the steam when partially expanded.

Illustration 1: Text from Henry Evers, LL.D., Steam and the Steam Engine: Land, Marine and Locomotive, William Collins, Sons \& Company, London, 1873, 82, 85 (the two paragraphs are not consecutive in the original) Diagram courtesy of the Archives and Collections Society. 
the Novelty was a Canadian attempt to define a solution. ${ }^{2}$

Early examples of compound engines were built in England by Jonathan Hornblower (1781) and Arthur Woolf (1803). These were stationary engines for industrial power, as were most subsequent developments. ${ }^{3}$ However, at the works of James Allaire, the premier North American engine builder in New York City, compound engines were installed in several vessels in the mid-1820s, beginning with the Henry Eckford (1824). ${ }^{4}$ Although demand for compound engines proved to be limited, the Allaire works continued to produce them, including an engine for the Buckeye State, launched in Cleveland in 1851. The engines were the design of John Baird and Erastus W. Smith. ${ }^{5}$ This was the second compound engine on the Great Lakes, having been preceded by the Oregon (1846-49), whose engines where built in Pittsburgh, to a design called "Clipper" after the first two western steamboats to use them. ${ }^{6}$ Meanwhile, in the Netherlands, Gerard Marits Roentgen equipped a number of steamers with compound engines beginning in the 1830s. The principal breakthrough is traditionally identified as the patent of Randolf and Elder in 1853 and the decision of the Pacific Steam Navigation Company to incorporate these into their paddle-wheelers operating on the west coast of South America. Even so, as late as the late 1870s Alfred Holt, one of the pioneers of compound engines, speculated that the shipping industry might still abandon compound for simple expansion engines. ${ }^{7}$

Given the widespread usage of compound engines in industrial establishments, why was there such a delay in the transferring the technology to steam navigation?

2 Denis Griffiths, Steam at Sea: Two Centuries of Steam-powered Ships (London: Conway Maritime Press, 1997), chap. 4.

3 Louis C. Hunter, A History of Industrial Power in the United States, 1780-1930 (Charlottesville, VA: University Press of Virginia for the Hagley Museum and Library, 1985) 2: 626-31.

4 Among the others were the Sun, Post Boy (1828) and three of the Swiftsure line, which combined tow boats with "safety barges." Philip W. Coombe, "The Life and Times of James P. Allaire, Early Founder and Steam Engine Builder" (Ph.D. dissertation, New York University, 1991), 178-79; John H. Morrison, History of American Steam Navigation (1903; repr., New York: Stephen Daye Press, 1958), 48.

5 Robert H. Thurston, A history of the growth of the steam engine (New York: D. Appleton And Co., 1878), 283; Morrison, American Steam Navigation, 376-77. National Archives and Records Administration, RG 41, Records of the Bureau of Marine Inspection and Navigation, Certificates of Enrolment and Registry, Cleveland, Buck Eye State, no. 33 of 1851, 15 July 1851.

6 Morrison, American Steam Navigation, 253, 376. On the Clipper design see Louis C. Hunter, Steamboats on the Western Rivers (1949; repr., New York: Dover Publications, 1993), 178, and of her spectacular explosion in 1843, p. 288. Sir Charles Lyell, A Second Visit to the United States of North America (New York: Harper \& Brothers, 1949), 223 describes a passage on the Clipper no. 2, including a passing reference to the Oregon: "her engines are of a very peculiar construction, hitherto used in sea-boats only, with the exception of one on Lake Erie."

7 Denis Griffiths, Steam at Sea: Two Centuries of Steam-powered Ships (London: Conway Maritime Press, 1997), chap. 4. 
William Redfield, a pioneering marine engineer in the New York region who had worked with these engines, argued in 1838 that the early experiments in compounding were rendered unnecessary as it became possible to raise boiler pressure to "intermediate" levels and to effect "an increased velocity of the piston." efficiency of the single cylinder engine were weighed against the complexity of the double cylinders. Adrian Jarvis reduces the answer to the challenge of boiler pressures. High pressure cylinders at the start of the cycle require high pressure steam; compound engines required higher pressure yet. Jarvis argues that the Board of Trade Inspectors appointed under the British Merchant Shipping Act of 1854 "erred on the side of caution, with the result that working pressures which were perfectly acceptable ashore were completely outlawed at sea." In North American inland waters, the Act had no jurisdiction, and routinely steam pressures above 60 psi were used. Nothing in the North American steamboat inspection laws and regulations set an upper limit to marine boiler pressures. Instead, each boiler was rated on its own merits. ${ }^{10}$ While Jarvis blames the regulators, Dennis Griffiths argues that delays in developing a reliable, high-pressure seagoing boiler warranted the caution of the Board of Trade inspectors. In any case, compound engines were significantly more expensive to erect, and then more complicated to maintain than single-expansion engines. If fuel was relatively inexpensive then savings on its consumption might not offset the other initial and routine (and non-routine) maintenance costs. ${ }^{11}$ These economic considerations applied as much on the Great Lakes as on the oceans.

In Canada, the leading figure in the development of the compound engine was Benjamin Franklin Tibbets. Born in New Brunswick in 1818, he worked in Fredericton before moving to New England. He returned to Fredericton in 1843, where he found backers for the construction of the Reindeer, equipped with his first compound engine design. Two months after her launch in September 1845 he is described as "of Montreal" in

8 Wm. C. Redfield to Hon. Levi Woodbury, 26 December 1838, printed in United States, Serial Set no. 345, 25 ${ }^{\text {th }}$ Congress, 3d Session, Executive Doc. No. 21 (13 December 1838), Letter from the Secretary of the Treasury transmitting ... information in relation to SteamEngines, etc., p. 422.

9 Adrian Jarvis, "Alfred Holt and the Compound Engine," in Robert Gardiner, ed., The Advent of Steam: The Merchant Steamship before 1900 (Conway's History of the Ship, Conway Maritime Press, 1993), 158.

10 Compare Province of Canada, Statutes, 14 \& 15 Vic. (1851), cap. 126 closely with United States, Statutes at Large, 1838, chap. 191 "An act to provide for the better security of the lives of passengers on board of vessels propelled in whole or in part by steam." The drafters of the Canadian act rewrote the US statute. The provisions for appointment and legal liability are necessarily slightly altered but sections IV-X are conceptually similar and by and large use the same language. The Canadian statute reflects the fact that Congress dropped the requirement for iron rods or chains to work the tiller in 1843 (US, Statutes at Large, 1843, chap. 94, sec. 2). The Canadian act requires that inspectors record on the certificate a limit to the boiler pressure permitted (sec. VI) and requires a steam gauge to be where passengers could view it (sec. VIII).

11 Griffiths, Steam at Sea, 46. 
the patent issued for the Province of Canada. Tibbets, however, settled in Quebec where, in conjunction with the family firm Pickersgill \& Tibbets, he promoted the Novelty, another steam vessel featuring his patented design. The bankruptcy of Pickersgill \& Tibbets by 1847 did not prevent B. F. Tibbets from building for other operators. Two other vessels are usually associated with Tibbets: the Madawaska (Grand Falls, NB, 1846) and B.F. Tibbets (Quebec, 1852). A second patent was issued in 1853 , but he could do nothing to exploit it. Tibbets died of tuberculosis that fall in Scotchtown, New Brunwick at the home of an uncle. ${ }^{12}$

Of Tibbets' designs, the engines of the Reindeer were particularly successful. Not only did they prove their speed and efficiency in races involving that vessel, but were transferred into the

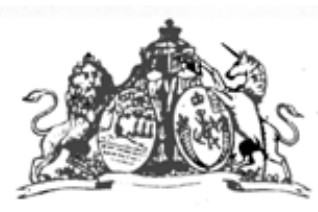

A. D. 1845-(Lower CN:NDA.)-No. 85.

Nero and imjroved Sleam Eragine.

LETIERS 1'ATEAT to Benjamia F. Thbets, of the City of Montroal,

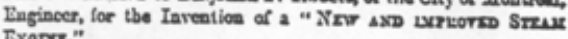
Dxorr."

Montral, dated 10th Norember, 195.

\section{war oscentnox.}

The inrention consists in using an expansion rewel of rextroir, intrudueed between a nan-coudensiag and a condensing engine, (v) cylinder of the non-cumdeasieg engine passing inte the said reacrois, and heing there expaniled to six or seren times its former bulk, and afterwaris jasaing in its expaseded state from the said renervoiz iato the eylinder of the condensing engive, where it may be again male to rork expansively to any exteat that may be ciesired, by wi hich means the suilden blow and heary strain upou the machiners, oressioned is the orlinnry expasuion engines by tho use of high jessure steas in a argo eyliniler, are effectually aroided, and the porrer rendered more equable at crery portion of tho atroke.

Seo Drwwing Sa. Ss.

BEXIAITN 2. TIDUETS.

Illustration 2: Tibbets' patent. Antelope in 1860-61, which was also considered a fairly swift vessel in her day. After the 1875 season, the engines were transferred yet again, this time into a new tug, Admiral, on the upper St. John River. The engine of the B.F. Tibbets had a significantly less distinguished career. The steamboat was transferred to the St. John River from Quebec in 1855 to tow timber. The following season she was burned and abandoned. Of the Novelty's engine, the first compound engine on the Great Lakes, significantly more can be said.

There were, in fact, two Noveltys. The first was launched in Quebec in 1847 and gutted by fire 18 miles below Montreal in the fall of 1850. She had been towing a raft of timber when she caught fire. The steamer had no boat, and only by running her ashore on a small island did those on board escape with their lives. A couple of days later, the salvage rights were auctioned at Quebec for $£ 495$, and the work of recovering the engine began. ${ }^{13}$

12 David McGee, "Marine Engineering in Canada: An Historical Assessment" (report for the National Museum of Science and Technology, Ottawa, 1995), chap. 2. J. J. Brown, Ideas in Exile: A History of Canadian Invention (Toronto: McClelland and Stewart, 1967), 95-97. Dr. George MacBeath and Capt. Donald F. Taylor, Steamboat Days: An Illustrated History of the Steamboat Era on the St. John River, 1816-1946 (Print'N Press, 1982), chap. 3. List of Canadian Patents, from the Beginning of the Patent Office, June 1824, to the $31^{\text {st }}$ of August 1872 (Ottawa: MacLean, Roger \& Co., 1882) nos. 85, 411.

13 Quebec Mercury, 17, 19 September, 1850; Library and Archives Canada (LAC), Record Group (RG) 12, A1, Shipping Registers, Port of Quebec, vol. 1406, no. 36 of 1848 (microfilm reel C-2061). 


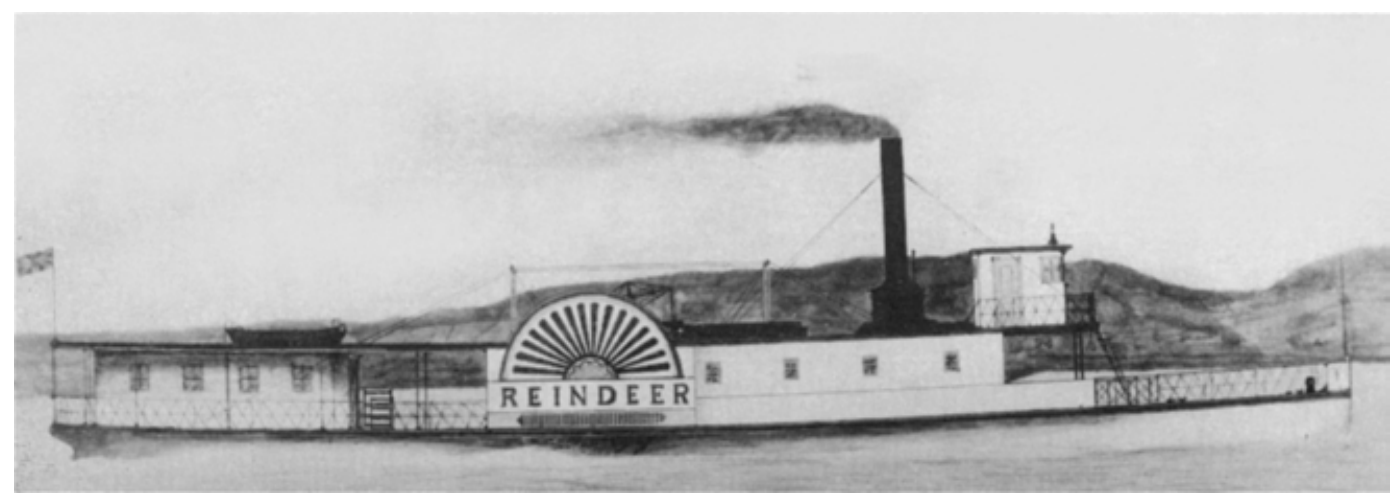

Illustration 3: The Reindeer, launched 3 May 1845 from the Nelson Mill yard, NB.

The second Novelty was launched at Quebec the following spring. She was 120 feet long as compared to the first vessel's length of 86 feet. Probably to accommodate the recycled machinery with a minimum of retooling, the new vessel was the same breadth as the first, 17 feet. Her imminent arrival in Kingston was anticipated in the "Spring Walks" of 1851, but the Whig cautioned "the Novelty has been taken up and handled so often during the past winter to suit the interested views of parties, that until she actually arrives in these waters, we will not believe in her purchase. She is said to be a 14 miles an hour boat, a very clipper in fact..." At the same time the Kingston newspaper disparaged her as "a strange kind of non-descript boat, appropriately called the Novelty." Offense was quickly taken by papers in Belleville where she would be owned and the Whig had to "back and fill." "The Novelty was called a 'nondescript,' by reason of the peculiar formation of her engine, which is constructed partly on the high pressure principle and partly on the low--the same steam is twice used--the term was not intended to be offensive." Still, it was only in September of that year when the Whig could finally proclaim that the "far-famed," "handsome," "speedy" if "somewhat crank" steamer had arrived in Kingston. ${ }^{14}$ It would not be the last time she ran late.

The service for which she had been acquired was one of the oldest steamboat routes on the Great Lakes: from Kingston to the head of the Bay of Quinte. For over thirty years, the Bay of Quinte route had been dominated by vessels built, commanded or owned by Henry Gildersleeve and his family. The Gildersleeve control of the Bay had been regularly contested by a variety of other parties since the late 1820 s but no one had lasted more than a few seasons. Jacob Bonter was one of the more persistent challengers having commanded the Kingston (1836), chartered the Brockville (1843), commanded and then owned the Prince Edward (1844-46), and chartered the Fashion (1848-50). ${ }^{15}$ By

14 Daily British Whig, 7 April, 21 April, 10 September 1851; LAC, RG 12, A1, Shipping Registers, Port of Quebec, vol. 1407, no. 30 of 1851 (microfilm reel C-2062).

15 Kingston Spectator, 28 April 1835; Chronicle \& Gazette, 6 September 1843, 1 May 1844; British Whig, 2 December 1845, 29 March 1848, 29 June 1850; Argus (Kingston), 4 December 1846. On the Gildersleeves see Edwin E. Horsey, "The Gildersleeves of Kingston: Their Activities, 1816-1930” (MS at Queen's University Archives, Kingston, 1942). 


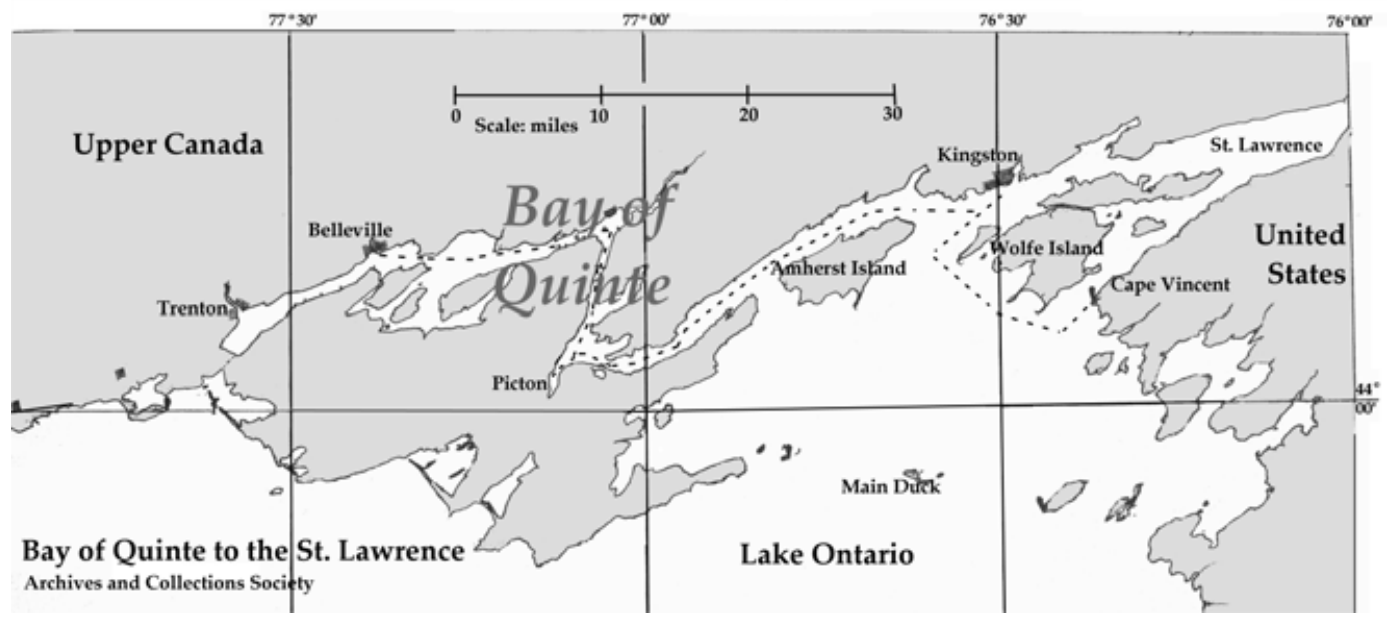

Illustration 4: Bay of Quinte to the St. Lawrence: common passenger and packet routes. Archives and Collections Society.

1852, he also owned the Charlevoix, running under the command of his son, John Cole Bonter, on a "through" route from the Bay of Quinte to Montreal. In 1853-54 he would own 14 of 64 shares in the Ste. Hélène, which would replace Charlevoix on this "through" route. With Fashion sold to Jacob DeWitt of Chateauguay in 1851, Bonter was back in the market for a steamboat for the shorter Kingston-Bay of Quinte trade. ${ }^{16}$

Traditionally Bay of Quinte steamers were smaller than the passenger vessels working the open lakes and the middle St. Lawrence. They worked quite sheltered waters: up the North Channel behind Amherst Island, to the narrow Bay of Quinte. At the same time, the landing places were quite undeveloped. Napanee, five miles up the shallow, marshy Napanee River, was a regular port of call, along with Amherst Island, Bath, Fredericksburg, Picton, Mill Point (Deseronto), Northport, Belleville and Trenton. Even though larger than its predecessor, at 120 feet the second Novelty fit the profile of a Bay of Quinte steamer quite nicely.

How then did Novelty and, more specifically, her compound engine perform? The purser Morgan's association with the engine builders probably led the Bonters to blame him for more than his share of the problems. John Masson, of the Kingston Foundry, would afterwards say that "Bonter's people [were] constantly coming to Foundry wanting something done to engine or boiler." In addition to the other problems, Novelty's boiler was designed to burn coal. Coal was available in Kingston in the fall of 1851, but wood was decidedly cheaper and available all the way along the route. In November Jacob Bonter contracted with the Kingston Foundry to replace the boiler over the winter with one that would generate greater steam pressure while burning wood. ${ }^{17}$

16 Daily British Whig, 12 April, 1 May, 22 June 1852; LAC, RG 42, vol. 176, Port of Montreal, no. 15 of 1851, 23 of 1853 (microfilm reel C-2466).

17 Archives of Ontario (AO), RG 22, Series 390, Judges Bench Books, John B. Robinson, box 29, no. 5, Midland District Assizes, Spring 1853, pp. 63-91, Bonter vs. Bruce. 
The new boiler was installed in time for trials in late April 1852,a short run up to Bath, cut short in part because of ice, followed by a longer run up to Belleville. The trials were unmitigated disasters. The boiler leaked. The crew had to refill it three or four times before getting under way. The foundry people were unsurprised that it leaked a little at first, most boilers did. They advised throwing in some rice. Bonter's crew did--12 pounds of rice in one trip. In fact, they were using 30 to 40 pounds of rice a week according to the purser, not to mention bran, and "Indian meal." Steam leaked into the furnace so badly it put the fire out. Indeed, leaking steam penetrated the cabin, frightening the passengers and dampening the bedding. While the main engine was out of gear at the wharf, the pump that forced water into the boiler was designed to be driven by a pony engine. But the pony's noises so disconcerted the passengers that the Bonters had ordered it disconnected the previous fall. Hand pumps were completely ineffective against the pressures required to drive the high pressure cylinder. The only solution was to let the fire die down, hand pump in cold water and heat it up again. Time consuming and inefficient, this procedure also put increased strain on the riveted boiler plates, flues and stays as they cooled down and were quickly reheated. The foundry recommended a blower; one was installed. The net effect on performance was to build up a major head of steam so that the vessel would leap away from the wharf, but it then gradually slowed to a crawl within three or four miles. Passage times ballooned from eight hours between Belleville and Kingston to fifteen or sixteen. The purser noted that they "did all they [could] to compete with the steam boats," but when asked whether they had raced the steamboat most of those associated with the Novelty just laughed. They were working like madmen just to keep her moving.

Nor were the problems confined to the boiler. It is clear that there were ongoing problems with the engine and the engineers. To replace Morgan, Bonter hired an American, John Donegan, whose experience combined work in high pressure tow boats on the Hudson river and six months in a shop with a compound engine. Shortly afterwards they let him go. He went to work on another local steamer. Six weeks later he was fired again and, despite reservations on both sides, returned to the Novelty. In the meantime Morgan had been brought back because the engine was also giving problems. Finally, in mid-July the Bonters bit the bullet and laid up the vessel in front of the Kingston Foundry. Ten weeks were lost while the foundry staff raised the engine under Morgan's directions. Another trial trip was made in September and Morgan was dismissed again. ${ }^{18}$

Leaping away from the wharf held its own risks. In late November 1852 she got aground up the Napanee River one Saturday night. On Sunday morning, having been worked off and as usual being well off her schedule, she got up a full head of steam and charged off down river. A pair of schooners, Dove and Tempest, were anchored downstream, and from the shift in winds had swung out into the regular channel. Both masters swore there was plenty of deep water towards the south bank but Novelty's crew proved indecisive and then unable to check their headlong rush before crashing into Dove. On board the Novelty the crew proved singularly inept. The pilot, John Culbertson, 
testified he did not understand the engine bells and so left them to the captain. The captain was John Talbot, who less than two months previously had been purser and testified "I do not know anything about the channel." The engineer claimed he did everything he was signalled to do, but was still in the process of responding to the "full reverse" signal when the collision occurred. In all, the evidence in the case suggested that the deck officers of the Novelty were indecisive and had no real sense of how long it took for their engineer to respond to commands. ${ }^{19}$ Clearly, having just gotten up steam, the Novelty was as frisky as she was likely to get. Possibly out of disgust with his own crew, Bonter chartered the steamer to Captain Thomas Maxwell in early December for $£ 4$ a day. Maxwell ran her across to Cape Vincent where the boiler and engine again failed. ${ }^{20}$

During the winter and spring of 1853 Novelty had major work on her boilers one more time. Frances Duncan was contracted to make the alterations. He declared that, apart from being inadequately staid, the boilers required a fire box of twice the size and more flues. Masson of the Kingston Foundry countered that he followed the "rule" for calculating the fire surface: 66 feet fire surface to each cubic foot of the cylinder. Masson had no direct contact with Novelty's engineer, William Morgan, in this process (perhaps because Morgan was so disgusted with the whole process he just wanted out of town). What does not appear to have been considered was the fact that the engine had more than one cylinder and maybe the old "rule" needed to be re-thought. Duncan certainly argued that point the following winter as he took his turn at trying to make the Novelty a better steamboat. $^{21}$

By this time Bonter was suing the Kingston Foundry for his losses because they had failed to make the boiler "in a sufficient \& workmanlike manner." In their defence the foundry staff argued that all boilers "leak a little at first" and that the actions of the Novelty's crew combined with a faulty safety valve and engine had led Bonter's employees to strain what would otherwise have been a perfectly acceptable boiler. The jury disagreed and awarded Bonter $£ 900$ in damages. ${ }^{22}$

Nor would this prove the end of Novelty's troubles with her machinery. Early in the 1854 season, a year after the trial with the Kingston Foundry, Novelty collided with Gildersleeve's Canadian (ex Prince of Wales) on a dark squally April night. Gildersleeve

19 AO, RG 22, Series 390, Box 58, no. 1, Kingston 26 October 1853, pp. 354-60, Hooper vs. Bonter. There is always the suspicion on a Sunday morning that some or more of those involved had been ashore in a Napanee "watering hole" the night before. This propensity may also be reflected in Donegan's spotty employment record but there is no evidence to confirm it.

20 AO, RG 22, Series 390, box 29, no. 5, pp. 63-91, Bonter vs. Bruce, testimony of Thomas Maxwell.

21 Ibid.

22 Ibid.; "The Assizes,"Daily British Whig, 2 May 1853, p. 2, col. 4, As a footnote to the trial, it should be noted that the rivalry on the Bay of Quinte was particularly intense between Bonter and the Gildersleeves. Kingston Foundry had a major contract for all the machinery, engine and boilers of Gildersleeve's new steamboat, Bay of Quinte. Gildersleeve in return supplied a number of officers and men to testify against Bonter at the trial. 
argued that the engines had given trouble, that Novelty was running late and off her regular course. Bonter countered that while she had been delayed by minor boiler trouble, at least she was showing her regular running lights! Novelty's new engineer, Charles Dowser, also noted that it was about a minute from the signal bells to stop and reverse until she struck. Gildersleeve won the case at the fall assizes and Bonter won the second round at the spring assizes; more significantly, Bonter won the favour of the appellate court. If nothing else, at least Novelty showed she could take more of a beating than the 11-year old Canadian; she finished the trip up the Bay and back before getting repairs to her bow. ${ }^{23}$

1854 it was generally known that Novelty was for sale. Construction was rapidly proceeding on the section of the Grand Trunk Railway line between Kingston and Belleville, while at the same time additional competition had arrived on the bay in the form of the City of the Bay (sometimes known as the City of Hamilton). The asking price for the Novelty was in the neighbourhood of $£ 3500$. Apparently some discussions took place about shifting her to a run between Rochester and Brighton, a new and untested route that would have connected with the Quinte steamers from the other side of Carrying Place, at the head of the bay. By the summer or fall of 1855 Novelty was sold to David Shaw, a Kingston wharfinger and one of the owners of the City of the Bay, and her name changed to Corra Linn. ${ }^{24}$

The change of name brought no improvement in her luck. Almost immediately she collided with the propeller Moira in the Bay of Quinte. Shaw won damages. In the

23 AO, RG 22, Series 390, Judges Bench Books, Richards, box 78, no. 4, Midland District Assizes, Fall 1854, pp. 16-45, 26 October1854, no. 22, Overton Smith Gildersleeve vs. Jacob Bonter and Henry Covert; R. E. Burns, box 58, no. 1, Kingston, 2 May 1855, Bonter vs. Gildersleeve, no. 1, pp. 340-43. Upper Canada, Court of Queen's Bench, Reports (UCQB), 12: 489-510.

24 Daily British Whig, 31 August 1854, p. 2, col. 1. LAC, RG 42, vol. 206, Port of Kingston, no. 73 of 1855, (microfilm reel C-1211). 
fall of the next year she was blown onto the Salmon Island shoal, about six miles above Kingston with 60 or 70 passengers on board. Rescue efforts failed; the crew of the Corra Linn having to rescue their would be rescuers. Finally she was lifted over some rocks onto a gravel bed only 60 feet or so from the island itself. When the storm let up Passport came out and took off the passengers. ${ }^{25}$

The end came on 30 October 1858. By this time Shaw had retreated from the Bay of Quinte, and the Corra Linn had been chartered for use on the upper St. Lawrence. On Lake St. Francis, just below Cornwall, she collided with the Fashion. Passengers and crew leaped onto the deck of the Fashion as Corra Linn went to the bottom. It is not clear whether the salvage efforts recovered the engine or other machinery from the wreck, but her owners were once again in court defending their actions and winning substantial compensation, in this case $£ 1,500 .{ }^{26}$

With this wreck, the history of the maritime use of the compound engine in central Canada comes to a close for a number of years. Apart from the short-lived Oregon and the Buckeye State on the upper Great Lakes, the appetite for experimenting with compound engines was quite limited. The compound era really started in earnest with experiments with the Perry and Lay design in Buffalo in the winter 1867-68. ${ }^{27}$ The next known instance of a compound engine on the Canadian side of the lakes was also at Kingston, the Maud, a composite steamer built in 1871 by the Gildersleeves for the Bay of Quinte route. Doubling the irony, her compound engine was built in Kingston, in a foundry also owned by the Gildersleeve interests. ${ }^{28}$

The introduction of compound engines is frequently held to have been the first major step towards the viability of the steam engine on salt water. But from 1853 until the late 1860s, when Americans began using Perry and Lay's design in engines largely built at Buffalo, steamboat owners on the Great Lakes ignored the innovation completely. ${ }^{29}$ Part of the reason may have been the general reluctance of passenger vessel owners to have much to do with "high pressure," but there were significant numbers of high pressure freight and towing steamers by the 1850s. The compound engine promised fuel efficiencies. But the new generation of cut-off valves patented by Corliss and others delivered, at least in part, on that promise without requiring specialized factory-trained engineers.

The Tibbets engine installed in the Novelty was a failure. Part of this may have been the result of stresses the engine suffered in the fire that destroyed the first Novelty. But significant numbers of marine engines were recovered from fire and shipwreck, rebuilt and went on to provide years of reasonably reliable service. The compound

25 Weekly British Whig, 26 October 1855, 26 September 1856.

26 Daily British Whig, 18 October 1858; 18 UCQB 541-47, Shaw vs. The DeSalaberry Navigation Company of Montreal.

27 Detroit Free Press, 1 April 1868 (reference courtesy C. Patrick Labadie from John E. Poole's notes).

28 British Whig, 17 August, 1871.

29 Buffalo Morning Express, 26 May 1869 (thanks to Bill McNeil for this reference); "Marine Engines," Buffalo Daily Courier, 1 May 1876. 
engine required higher steam pressure than single cylinder, high pressure engines. Neither of Novelty's first two boilers supplied that; nor did the boiler makers concede the stresses on their products that running at $100 \mathrm{psi}$ rather than 60 were producing. Finally, engines depended on good marine engineers to operate them. Bonter seemed to have trouble recruiting and keeping such men. In the end, reliability was vastly more important to the shipowner than fuel savings or potential improvements in speed. In New Brunswick, the Reindeer's compound engine proved reliable. On the Lakes, the Novelty's did not.

\section{Appendix.}

LAC, RG 12 A 1, vol. 196, Shipping Register Quebec, no. 30 of 1851.

Information required in Registering Steamers

Number of Engines: two

Horse Power: one 40, one 30 horsepower

Length of stroke \& number pr Minute at full speed: 4 feet no. pr min 36

High or Low pressure: One low 40, One high 30

Diameter of Cylinder, in inches: One $40 \& 418$ [48?] high press

By whom made: B. Tibbets

Greatest speed pr hour: 15 miles

Quantity of coals carried in Boxes: 18 Chaldrons

Quantity consumed pr hour: 6 Bushells [sic]

Diam'er of Paddle Wheels: 14 feet

Revolutions pr minute: 36 Revolutions

How employed: Passage boat from Quebec to the Bay of Quinte

Vessels Name: "Novelty" 